\title{
How crucial is the social responsibility for tourism sustainability?
}

\author{
Martina Paskova and Josef Zelenka
}

\author{
Martina Paskova and \\ Josef Zelenka are University \\ Teachers, both at the \\ Department of Recreology \\ and Tourism, Univerzita \\ Hradec Kralove, Hradec \\ Kralove, Czech Republic.
}

Received 6 March 2018 Revised 9 May 2018

4 June 2018

2 July 2018

Accepted 15 July 2018

(c) Martina Paskova and Josef Zelenka.Published by Emerald Publishing Limited. This article is published under the Creative Commons Attribution (CC BY 4.0) licence. Anyone may reproduce, distribute, translate and create derivative works of this article (for both commercial and non-commercial purposes) subject to full attribution to the original publication and authors. The full terms of this licence may be seen at http://creativecommons. org/licences/by/4.0/legalcode

This research was financially supported by the Faculty of Informatics and Management of the University of Hradec Králové (FIM UHK) in the frame of the Specific Research Project "Information and knowledge management and cognitive science in tourism". The authors thank Jan Hruška, FIM UHK student, who assisted with the graphical elements of this contribution.

\begin{abstract}
Purpose - The paper aims to analyse the social responsibility concept and to explore its role in the implementation process of the tourism sustainability concept. The intention is to explore the way in which the social responsibility concept is implemented in the tourism and analyse how it contributes to its sustainability.

Design/methodology/approach - In this interpretivist research, the authors implemented a qualitative strategy using the following methods: content, critical and comparative analyses of the results reported in available scientific studies, categorization, causal analysis and mental mapping. The authors identified 14 thematic categories of research on the tourism social responsibility. For the causal description, the authors used driving force, pressure, state, impact, response (DPSIR) method.

Findings - The results include identification of the categories of the research topics concerning tourism social responsibility as well as categories of the approaches to the implementation of the social responsibility into the practice of the tourism sector. The causal description of this implementation process is elaborated in the form of the DPSIR model. The created mental map shows the specific facets of the social responsibility concept applied to the diverse tourism subsectors.

Originality value - The main contribution lies in basic overview of the conceptual (theoretical) and instrumental (practical) base for implementation of the social responsibility concept into the tourism, providing in this way a critical analysis of examples of the social responsibility practice in the key tourism subsectors. The examination of the causal analyses in the form of DPSIR model as well as employment of the content analyses in the form of mental map represent innovative approach to the tourism responsibility research.
\end{abstract}

Keywords Social responsibility, Tourism impact, DPSIR, Mental map, Tourism sustainability

Paper type Conceptual paper

\section{Introduction}

Knowledge of implementation effects of both personal and corporate responsibility for tourism-related behaviour seems to be important for tourism future viability (Levy and Park, 2011; Chen et al., 2012; Martínez and del Bosque, 2013; Benavides-Velasco et al., 2014; Kang et al., 2015; Seo et al., 2015; Pásková and Zelenka, 2016). The same pays for knowledge of implementation effects of tourism sustainability concept (Butler, 1980; Tosun, 1998; Weaver, 2006; Choi and Sirakaya, 2006; Budeanu, 2007; Pásková, 2012; TorresDelgado and Palomeque, 2012; Bonilla-Priego et al., 2014). However, what about knowledge regarding the relationship between these two phenomena? How much, in which ways and with which results are studied the effects of the social responsibility implementation in tourism for its sustainability?

The social responsibility studies operate most commonly with two following terms: corporate social responsibility (CSR) and the corporate social and environmental responsibility. To be able to apply the responsibility concept to the whole spectrum of the tourism actors and forms, the authors use the general term "social responsibility", which includes its economic, sociocultural and environmental dimensions at individual, local, regional and global levels. 
Social responsibility application in tourism has undergone during its relatively short history changes mainly in following ways: in terms of the scope of its content, its geographical scale (beginning at local and ending at global), its level of holisticity and its mode of tourism actors' involvement. The previous mentioned change reflects the growing level of collectivism of tourism actors' involvement describable as continuum starting with an individual responsibility and ending with the government responsibility.

Regarding the change of the tourism responsibility scope, the motivational, relational and conceptual starting point (Table I) indicates the social responsibility performed by increasing number of tourism actors' groups with different interests. These actors are represented not only by stakeholders of both supply side and demand side but also by the stakeholders who are not direct participants in the tourism industry market. The representatives of the travel agencies, airlines, cruises and bus transport companies, as well as accommodation facilities, interpretative centres, attractions' managers, tourist guides etc. are among the basic supply side stakeholders who are already trying to accept and implement their social responsibility through incremental tourism sustainability. Some visitors' segments representing demand side stakeholders already request the socially responsible tourism services. There are also national tourism organizations, local authorities and local inhabitants not directly participating in but substantially influencing tourism market and sustainability in the given destination. Regarding holisticity and complexity, it developed from social and economic aspects of the tourism responsibility, later involved environmental approach and finally arrived to the holistic and systemic concept of the

Table I Possible categorization of the approaches to the tourism social responsibility

Topic

The motivation for the introduction of social responsibility among tourism companies and destinations

Economics of implementation of social responsibility

Measurement and evaluation of social responsibility of tourism organizations and destinations

The implementation of corporate social responsibility as a factor of competitive advantage

The difference between declared social responsibility and real social responsible behaviour/corporate market performance Specifics of social responsibility in the key sectors of tourism industry

Increase/decrease in quality of the tourism product the context of implementation of social responsibility and consumers willingness to pay higher/same price

The willingness of the various tourism actors to support or implement social responsibility

The collective system of values and individual social responsible behaviour

Satisfaction of visitors/guests with the implementation of (corporate) social responsibility

Discussion of visitors' social responsibility, including discussion of patterns of visitors' behaviour and in relation with their psychographic characteristics

Discussion of social responsibility used by the local community

Perception of the social responsibility by staff of tourism organizations and influence of social responsibility on their behaviour

The social responsibility and optimization/prevention/ internalization of tourism market externalities
Related authors (examples)

Garay and Font (2012), Font et al. (2016), Jha and Cox (2015)

Kang et al. (2010), Asatryan (2012), Coles et al. (2013), Singh et al. (2014), Kang et al. (2015)

UNWTO (2004), De Grosbois (2012), Matev and Assenova (2012), Bonilla-Priego et al. (2014)

Levy and Park (2011), Inoue and Lee (2011), Chen et al. (2012), Martínez and del Bosque (2013), Benavides-Velasco et al. (2014), Kang et al. (2015), Seo et al. (2015), Hagmann et al. (2015)

Frey and George (2010), Font et al. (2012), Juvan and Dolnicar (2014)

De Grosbois (2012), Bonilla-Priego et al. (2014), Zelenka and

Pásková, (2016)

Kalafatis et al. (1999), Kim and Han (2010), Kang et al. (2012), Lu and Shon (2012), Mayer et al. (2012), Chen (2013), Kucukusta et al. (2013), Parsa et al. (2015), Hagmann et al. (2015), Seo et al. (2015) Budeanu (2007), Kang et al. (2012), Huang et al. (2014), Parsa et al. (2015), Han and Yoon (2015)

González-Rodríguez et al. (2015)

Lee and Heo (2009), Martínez and del Bosque (2013), Gao and Mattila (2014), Siu et al. (2014)

Kim and Han (2010), López-Mosquera and Sánchez (2012), Caruana et al. (2014), Huang et al. (2014), Sin and Minca (2014), Han (2015), Chen (2015), Mancha and Yoder (2015)

Su et al. (2013), Sin and Minca (2014)

Bauman and Skitka (2012), Tsai et al. (2012), Aminudin (2013),

Farooq et al. (2014), Kang et al. (2015)

Argandoña (2010), Pásková and Zelenka (2016)

Source: Pásková and Zelenka (2016), substantially extended 
tourism responsibility. According to many authors (UNEP/UNWTO, 2005; Fons et al., 2011; Zelenka and Pásková, 2012; Pásková, 2012, 2014a, 2014b; Pásková and Zelenka, 2016), responsible tourism is based on the continual search for the dynamic equilibrium of sociocultural, environmental and economic dimensions. Based on the above-mentioned investigations' results and analyses (see references indicated in the Table I), it can be postulated that motivation, communication and marketing are crucial for ensuring a real state of dynamic equilibrium, balancing the interests of the key tourism actors and especially, in the form of an appropriate management, mainly at the destination level.

In spite of numerous observations reported on social responsibility implementation in various tourism subsectors, the mechanism of this process and its results for tourism sustainability remain unclear. Hence, the authors' intention is to analyse the way in which the social responsibility concept is implemented in the tourism sector and how it contributes to the tourism sustainability. The identification of the concrete examples helps to elaborate structuration of the current application of social responsibility theory in tourism sustainability practice. Causality analysis is important for understanding of mutual interrelationships between supply side and demand side representatives and other stakeholders, intrinsic and extrinsic motivations, barriers, changes and their effects as well as a stakeholders' feedback. Authors strive to gain deeper comprehension of the process of tourism sustainabilization through the implementation of the social responsibility and to elucidate links and mutual interconnections between various both actors and factors of this process.

\section{Theoretical bases}

According to Pásková and Zelenka (2016), the core of tourism unsustainability lies with the unrecognized contribution and unaccepted responsibility for negative tourism market externalities generated by both the demand and supply side of tourism market. Neoclassical environmental economics (van den Bergh, 2001; Illge and Schwarze, 2006, 2009; Beder, 2011) provides the theoretical base for the concept of market externalities (Beder, 2011; Silvis and van der Heide, 2013; Phaneuf and Requate, 2017), some authors use even the term "sustainability economics" (van den Bergh, 2001; Illge and Schwarze, 2006, 2009). Negative environmental, economic and sociocultural tourism market externalities are originating during the processes of the production, distribution and consumption of tourism services, as well as during both construction and use of the related infrastructure. They have form of harmful effects to the local inhabitants and/or the environment not only in the tourism destinations but also in the tourism source regions (Pásková, 2012; Pásková, 2014a, 2014b). These effects cause different forms of tourism market failure, which contribute substantially to tourism unsustainability. This is because the tourism collective and individual actors do not take into account the uncalculated (mostly immaterial) costs of their activities to the population and its heritage as well as to the environment. The above-mentioned costs are not included into the price of the tourism product, because they cannot be easily expressed in financial terms. Insufficient education and still weak awareness about possibilities of application of the ecosystem services concept do not help solve the tourism market externalities and thus tourism unsustainability in general.

The cognitive science (Sternberg and Sternberg, 2016) is giving the base for the description and analysis of the situation in tourism social responsibility in the form of the mental mapping (Pásková and Zelenka, 2016; Zelenka and Pásková, 2016). The theories of ecological processes (Begon et al., 2005) are providing base for analysis of the processes related to the tourism social responsibility in the form of the driving force, pressure, state, impact, response (DPSIR) causal model which can be applied also in the field of the tourism research (Pásková, 2012). The DPSIR method describes the causal chain of the anthropogenic impacts on the environment, especially on specific ecosystems (Stanners and Bourdeau, 1995; Gari et al., 2015). The title of this model represents an acronym 
derived from following terms: driving force, pressure, state, impact and response (Stanners and Bourdeau, 1995). These terms represent the main processes observed in the causal chain of the human impacts of their environment. "Drivers" are impulses emitted by human societies and business companies as well as related changes and they are based on human needs and they represent the cause of pressures (Pirrone et al., 2005; Kristensen, 2004; EPA, 2016; Hak et al., 2012; Koundouri et al., 2016). These driving forces may be, for example, the increasing energy intensity of tourism infrastructure, the need for luxury tourism facilities or mass tourism in general. "Pressures" are the results of driving forces, e. g. emissions of greenhouse gases, noise, vibration, radiant energy or waste production (Pirrone et al., 2005; Kristensen, 2004). "State" includes all current variables whose value can be measured or assessed, e.g. air quality, quantity and quality of both surface and underground water, landscape fragmentation, changes in water regime, energy flows, food chain, sodium content in soil, the average age or size of the population of plant or animal species, as well as the qualitative and quantitative state of the human population (Pirrone et al., 2005; Kristensen, 2004). "Impacts" are caused by "drivers" and "pressures"; they have an influence on the way, possibilities, limits and quality of life of animal and plant species as well as the human population. Examples of "impacts" are, for example, the decreasing size of plant and animal territories, the contamination of their habitats, the decrease in availability and variety of food, the increasing incidence of invasive species, the decreasing human resistance (e.g. due to increased isolation from the natural environment, contaminated food and disturbed biorhythm; Pirrone et al., 2005; Kristensen, 2004). These impacts affect substantially the human life, mainly in sectors such as agriculture, fisheries, forestry, medicine and food. "Response" is the reaction to "impact". Usually, this feedback takes the form of various preventive or regulative measures as decrees, strategies, concepts, innovations, laws, or regulations and restrictions. The purpose of "response" is to mitigate, replace or even prevent pressures as well as to improve, compensate or adapt to the emerged situations (Kristensen, 2004; Hak et al., 2012). An example may be a total or selective ban on entering a cars, declaring a protected area, promoting waste recycling and financial support for sustainable projects, using alternative energy sources or implementing organic farming (Kristensen, 2004; Hak et al., 2012).

Application of this method for description of causal links in the field of ecology (BenitezCapistros et al., 2014) was first indicated in the report on the state of the environment in Europe (Stanners and Bourdeau, 1995) and deeper elaborated in its updated edition in 1998. The DPSIR model is used to simulate many environmental processes, including the management of water resources (El Sawah and Guillaume, 2011; Pirrone et al., 2005) and modelling of climatic change effects (Omann et al., 2009) and for structured conceptual approaches, e.g. for management of sustainable development in the EU (Tsai et al., 2009). The DPSIR model represents a great opportunity for tourism modelling including use of artificial intelligence that can capture the interrelationship of impacts in the destination and their effects on the decision-making of visitors, local inhabitants, tourism business people and other tourism stakeholders. Ojeda-Martínez et al. (2009) applied the DPSIR model for description of the integrated management of marine protected areas with consideration of tourism activities. This method can be used to describe a typical course of its environmental impact, for example in studying carrying capacity of the tourism destination (Coccossis et al., 2001, p. 56; Castellani and Sala, 2012; Jurado et al., 2012) and in developing comprehensive indicators of tourism sustainability (Choi and Sirakaya, 2006; Fernández and Rivero, 2009, pp. 284-285; Castellani and Sala, 2012).

Pásková (2014a, 2014b) draws attention to the fact that the DPSIR model is often used on a one-sided basis, in particular when assessing just the adverse effects of human activities (e.g. tourism) on the environment, despite the fact that it can stimulate also beneficial landscaping effects, enhancement of the local cultural identity, original regional production and other positive socio-economic impacts. For example, Lamorski and Dabrowski (2007) in their study of the impacts of tourism in the Babia Gora National Park, alongside the 
negative impacts (in particular the erosion caused by visitors, vegetation and fauna damage), describe the positive socio-economic and environmental impacts of tourism (support of consumption of the organic farming products and related landscape care). Also in the study of tourism activities in Cyprus (Spanou, 2007) many positive sociocultural tourism effects were identified, e.g. awareness of the importance of cultural heritage, restoration of traditional festivals, availability of hand-crafted products and renovation of historic buildings.

\section{Methodologic approaches to the researched issue}

In this interpretivist research, the authors implemented a qualitative strategy using the following methods: content analysis, critical and comparative analysis of the results reported in available scientific studies, categorization, causal analysis and mental mapping. The content of the current studies concerning the tourism social responsibility was analysed and as a result, the 14 categories of this research topic were identified. On the basis of critical and comparative analyses, authors then selected few studies relevant for each of the identified category and the content of these studies they analysed in detail. The criteria for selection of these studies were the level of their methodologic correctness and mainly the level in which they corresponded with the topic of given category. Elaboration of the mental map of the social responsibility aspects of various tourism sectors was based on content analysis of available academic writings (Pásková and Zelenka, 2016, p. 782; based on ideas of Kang et al., 2010; Chen et al., 2012; Garay and Font, 2012; Parsa et al., 2015). For the causal description of the implementation of social responsibility in the tourism sector, the above-described DPSIR method was used. The IHMC CmapTools has served as a software environment for creation of visual representations of mental maps of tourism social responsibility. Arriving at all the results as well as the final synthetic conclusion was facilitated also by the rich authors' personal knowledge and experience, as well as by the deductive application of relevant concepts of the tourism sustainability (Pásková, 2012; Pásková and Zelenka, 2016).

In contrast with prevailing anthropocentric approach, the authors strived to conduct this study in an alternative geocentric context with the aim to obtain a real holistic picture, more relevant for tourism sustainability. In this context, the Earth and its resources are regarded and respected as an essential base not only for the tourism development but also for life as such. This geocentric approach is helpful for deeper understanding of the human position in ecological systems and thus it can assist for more holistic analysis of both individual and collective respect of tourism actors for the Planet, which transcends human needs. For these reasons, the geocentric concept frames the analysed relation between the concepts of tourism sustainability and tourism social responsibility as illustrated in the Figure 1.

\section{Results}

General respect for the Earth, mutual tolerance and fair distribution of both positive and negative effects of tourism among tourism actors are at the core of the tourism social responsibility. According to this acknowledgment, authors classify approaches to tourism social responsibility, they describe and analyse the situation, causality, processes and feedback of this phenomenon both in the tourism market and outside of it in the form of mental maps and ecological causal model.

\subsection{Overview of social responsibility implementation in tourism sector}

Research of social responsibility in general has been focussed on corporate actors' motivation and implementation process, measurement of social responsibility effects, role of environmental and social responsibility in promotion and competition, determination of the gap between declared and performed social responsibility, social responsibility perception 


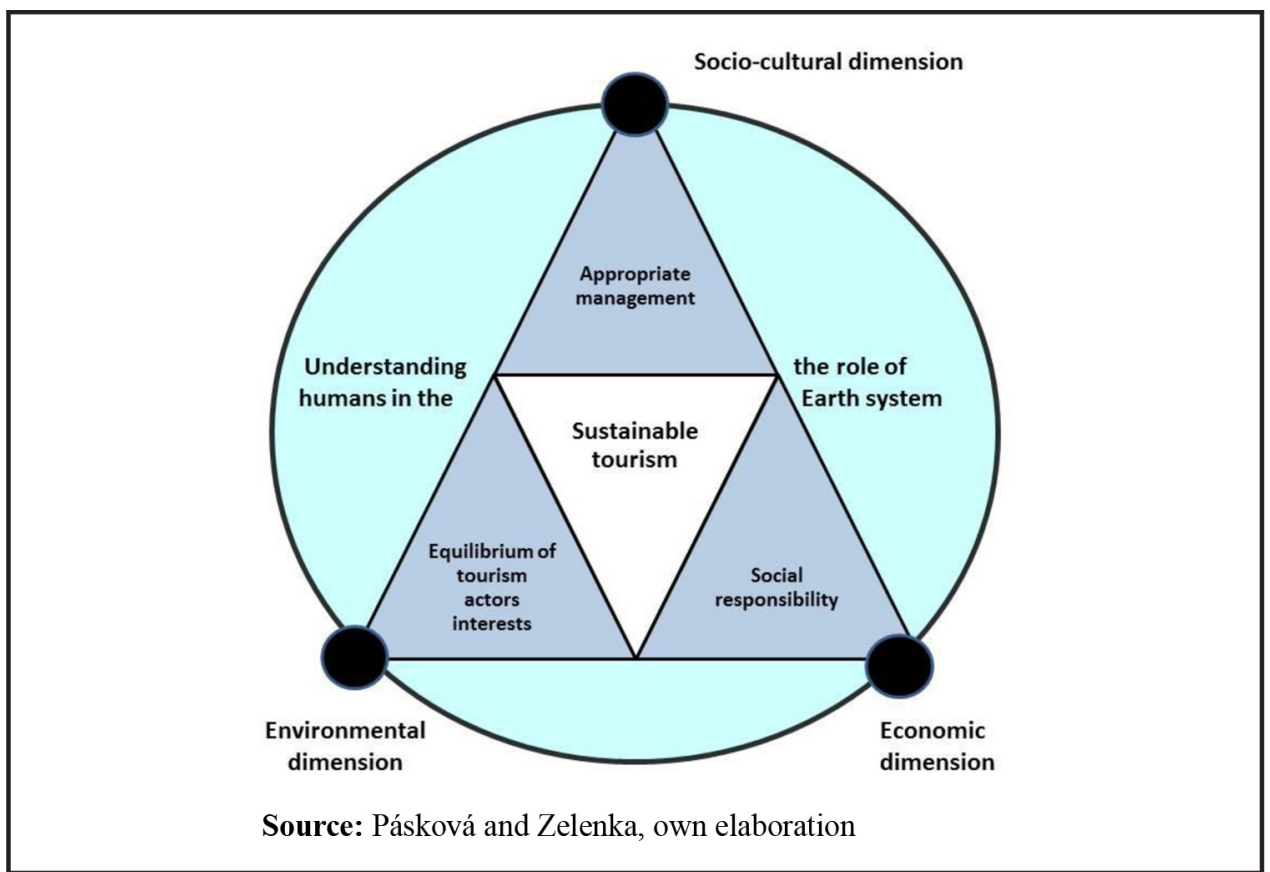

and other topics. There are some tourism specific topics in this field of study (Table I) including measurement, evaluation, perception and performance of tourism social responsibility or optimization of tourism effects, mainly prevention and compensation of negative tourism impacts. Authors have categorized them into the 14 thematic clusters and for each of them they have selected few illustrative studies.

\subsection{Actors of tourism social responsibility}

Research topics regarding tourism actors are oriented on their social responsibility motivation factors (Table I, point 1). This includes their willingness to support or implement social responsibility (Table I, point 8 ), their behaviour including the collective system of values as well as individual social responsible behaviour (Table I, point 9), their perception of social responsibility and related changes in their behaviour patterns (Table I, point 13).

According to the importance of the visitors as key actors in the field of socially responsibility tourism, substantial attention is paid to researching the social responsibility of visitors. This involves the willingness of visitors to pay higher or the same price for the tourism product, of which quality has either increased (e.g. environmental standard) or decreased (e.g. comfort level) in the context of implementation of social responsibility (Table I, point 7). The other cases include their willingness to support implementation of the social responsibility (Table I, point 8). The important research topics represent the satisfaction of visitors with both process and results of the implementation of social responsibility (Table I, point 10) as well as their social responsibility performance in the context of their behaviour patterns related to their psychographic characteristics (Table I, point 11).

\subsection{Selected approaches, methods and concepts of tourism social responsibility}

Based on the content and comparative analyses of the academic writings concerning the topic of social responsibility implementation into the tourism sector as well as on their own 
knowledge, experience and research (Pásková and Zelenka, 2016), the authors suggest bellow described categorization of the approaches to the implementation of the social responsibility concept into the practice of the tourism sector.

4.3.1 Information and analytical approach. This approach facilitates data availability on projected and real impacts of various tourism subjects' performance on society, the environment and tourism sustainability. This typically includes companies' non-financial reporting, monitoring of the tourism sustainability and environmental accounting. This approach represents the basis for communication with tourism decision-makers and other tourism actors (tourism service providers, destination management organization, etc.) as well as for tourists' choice of tourism services and destinations. Non-financial corporate reporting shows the intended content of social responsibility, especially its implementation, which provides the ability to control it by various tourism actors. Non-financial monitoring is a societal control tool for rating corporate responsibility of the reporting entities. This instrument is relatively widespread in tourism sector, mainly at hotel chains (Cherapanukorn and Focken, 2014; Đurović et al., 2015). Sustainability monitoring includes sustainability indicators (UNWTO, 2004 and Choi and Sirakaya, 2006); they include ecological footprint (Hunter and Shaw, 2007) and carbon footprint (Munday et al., 2013; Cadarso et al., 2016; Gössling and Buckley, 2016, etc.). Environmental accounting complements the conventional accounting for economization of common goods; its employment in sustainable tourism in general indicates Garrod and Fyall (1998).

4.3.2 System approach. This approach envisages the implementation of subsequent changes in the management of the entire organization, alternatively with the support of international standards for environmental management. Lynes and Andrachuk (2008) analyse ISO 14000+ implementation in Scandinavian Airlines. Akmese et al. (2016) compare application of CSR between tourism and financial sectors, the normative guidelines are available in SA 8000 or ISO 26000 (ISO, 2016). Batle et al. (2018) deal with the EMAS (EU environmental management directive, similar to ISO 14000+) employment in tourism industry. This approach involves also philosophy and methods of total quality management (TQM) or total quality environmental management (TQEM). Witt and Muhlemann (1994) elaborated guidelines for the implementation of TQM in tourism, and Benavides-Velasco et al. (2014) describe the employment of the TQM for hotels.

4.3.3 Compensation approach. In this approach, a negative tourism impacts are compensated for at the point of origin (e.g. felling of forests for construction of tourism infrastructure is offset by reforestation project in the vicinity) or at an appropriate place compensated by a publicly beneficial project (Argandonõa, 2010). Frequently, tourism negative externalities do not affect some specific locality, e.g. the airlines which compensation programmes are implemented by themselves (e.g. by afforestation projects in Africa), respectively with the participation of passengers typically through the offset programmes (Lu and Shon, 2012; Chen, 2013; Hagmann et al., 2015).

4.3.4 Delegation (client) approach. This approach means that the tourism subject, e.g. hotel or destination management organization, delegates responsibilities to its clients (guests, visitors, etc.). In its financial form, the full delegation means a complete inclusion of the environmental and social costs of tourism (internalization the tourism externalities) into the price calculation of the tourism product. This case can be implemented in the form of environmental taxes (Palmer and Riera, 2003). The partial delegation represents the situation, when the client contributes to prevention or reimbursement of tourism environmental and social costs voluntarily (e.g. offset programmes, participation in social responsibility activities or projects. Singh et al. (2014) describe the employment of this partial delegation approach in the hotel industry and recommended guest involvement in recycling programmes.

4.3.5 Preventive approach. As the most effective approach to the social responsibility implementation authors perceive the case when the tourism company tries throughout the 
all the product lifecycle (or the destination lifecycle) to prevent generation of the adverse societal and environmental impacts, even at the price of cost increase, e.g. by investment into human resources or innovation of the destination or product. Campbell et al. (2015) describe prevention of those adverse impacts on the case of FairTrade. Mathew and Sreejesh (2017) demonstrated that tourism impacts prevention in the form of responsible tourism is perceived by local residents as an important factor both of the destination sustainability and the quality of their lives.

4.3.6 Educational approach. This approach concerns the implementation and clarification of principles whose understanding may lead customers to more sustainable patterns of their behaviour. Geoparks as innovative geotourism destinations and their geotourism products can serve as an example; they stress an interpretation of all the processes connected to the presented phenomena as well as the feedbacks of related tourism activities (Dowling and Newsome, 2006; Farsani et al., 2012; Dowling, 2013; Pásková, 2014a; Pásková 2015).

4.3.7 Regulatory approach. This approach represents an instrumental base for land use regulation and execution of the related processes. These rules are set in tourism sector, e.g. for emission limits (Argandoña, 2010) and protected areas (Pásková, 2012; Pásková, 2014a, 2014b). They can be also determined by application of the carrying capacity concept (Zelenka and Kacetl, 2014) and derived through tourism impact evaluation, e.g. through the concept of limits of acceptable change (LAC) and many of the approaches of the visitor management. Zelenka and Kacetl (2013) discuss the visitor management practice and Pásková (2012) describes the employment of the concepts of both carrying capacity and LAC in tourism sector. This approach needs to be implemented with knowledge of related processes (Zelenka and Kacetl, 2014), administrative-economical background (e.g. using taxes as described by Palmer and Riera, 2003) and in the context of market regulatory mechanisms, typically emission allowances discussed for the case of the air transport by Qiu et al. (2017).

4.3.8 Marketing approach. This approach is based on advantage, which stems from the promotion of commitments and results achieved by social responsibility implementation. Buckley (2002) gives the example of environmental certification promotion, while Pásková (2014a, 2014b) describes tourism environmental marketing in general and related targets. An important part of the marketing approach represents certification, facilitating comparable and guaranteed results of social responsibility. As shown by Blackman et al. (2014) on the example of case study conducted in Costa Rica, Blue Flag eco-certification scheme can directly affect the investment activity in the hotel chain.

\subsection{Causality of social responsibility implementation into the tourism sector}

There is some causality behind the process of the implementation of the social responsibility concept into the tourism sector. This process can be described in the form of DPSIR scheme. This model seems to be instrumental for description and comprehension of the causes, manifestations; effects and feedback of the implementation process of the tourism social responsibility (see Figure 2). DPSIR model is used predominantly for causal description of negative environmental impacts, but when describing the implementation of the tourism social responsibility, it illustrates positive causality.

The recognition of negative impacts of the tourism market and acceptance of responsibility for contributions to these impacts represent the driving forces behind the implementation process of tourism social responsibility. These driving forces cause the pressures both on the demand side and the on the supply side. The visitors begin to ask for tourism products, which do not negatively influence the quality of life and environment of the local population. At the same time, some suppliers start to select materials and human resources, which do not destroy the quality of life. These pressures cause changes in the tourism market, which 


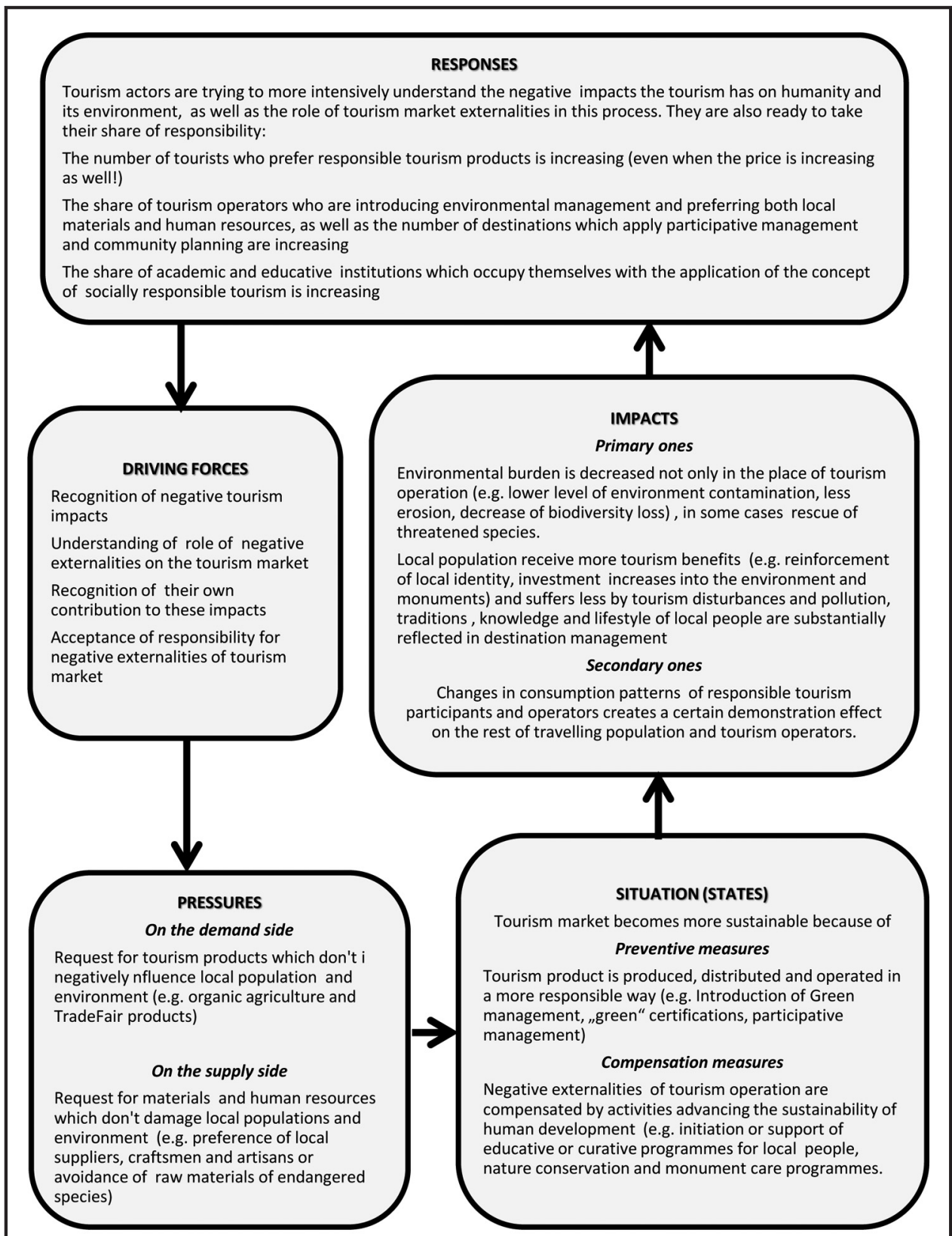

Source: Pásková, own elaboration

becomes gradually more sustainable because of implementation of the both preventive and compensation measures. Tourism products are generated, distributed and operated in a more responsible way and at the same time, the negative externalities of the tourism operation are prevented, internalized or compensated by activities advancing the sustainability of human development (e.g. provision of educational or curative programmes for local people or support for nature conservation and monument care activities).

This change in the tourism market causes both primary ones and the secondary impacts. As the secondary impacts, the environment is less burdened not only at the tourism 
destination but also in the place of visitors' origin, in some cases it even causes the rescue of monuments or species. Local populations receive more tourism benefits and suffer less by tourism disturbances and pollution. Traditions, knowledge and lifestyle of local people are reflected in the increasing extension in decision-making process of the destination management. As the secondary impacts, the changes in the consumption patterns of responsible tourism participants and operators create certain demonstrative effect not only on the travelling population and tourism operators but also on the public, including family, friends, colleagues and neighbours.

These impacts create feedback in of various forms. Tourism actors gradually try to understand the negative impacts of tourism on humanity and its environment and they become ready to take their share of responsibility. In this way, the segment of tourism participants who prefer responsible tourism products increases. In addition, there is an increase in the number of tourism operators who introduce environmental management and prefer local materials and human resources and who use participative management and community planning in the decision-making process of their destination management. The number of academic and educational institutions, which study the implementation of the concept of tourism social responsibility, is also gradually increasing.

It is obvious that DPSIR model represents an important and instrumental method not only for research and education but also for the destination management and relating marketing. If applied to concrete cases and distributed in the form of comprehensive stories, it can stimulate the tourism actors to join the process of the tourism social responsibility.

\subsection{Mental map of social responsibility implementation into the tourism sector}

Mental mapping represents a useful method for the analysis of emerging complex social phenomena. Mental map of the fundamental aspects of social responsibility as related to tourism sustainability, based on ideas of different authors, is shown in the Figure 3 . The essential relation between the social responsibility concept in the tourism industry and its sustainability is clearly illustrated there by the interconnection of the mission, basis, perceptions, reflections and determinants of the social responsibility concept in the tourism sector, as well as by the determination of the influencing factors. The mental map also describes the role and positions of various tourism actors in promotion, introduction and implementation of the concept of tourism social responsibility, as well as the identification of diverse motivations for introducing this concept to the tourism market. The existing and possible ways to implement this concept are also present in the whole picture.

\section{Discussion and conclusion}

Research on the social responsibility implementation in tourism sector was categorized into the 14 thematic clusters; however, it cannot be regarded as complete or even final because of its dynamic development. The same applies for categorization of the approaches to the implementation of the social responsibility concept into the practice of the tourism sector. Both categorizations cannot avoid some thematic overlapping, e.g. in the cases of the preventive and educational approaches.

A brief analysis of the actors of tourism social responsibility shows the visitor as a decisive stakeholder and the catalyst for the internalization of tourism market externalities. However, his/her willingness to pay higher price or willingness to relent his/her demands on comfort and thus to prevent some of negative tourism externalities are limited. These barriers may consist in insufficient visitors' knowledge of tourism market externalities and related problems, in their insufficient moral background and strongly embedded incorrect patterns of their consumption behaviour or in the feeling lack of sense and effect of their responsible behaviour. These limits can be overcome mainly with the help of the increased awareness raising and environmental education as well as by the systematic introduction or support of 


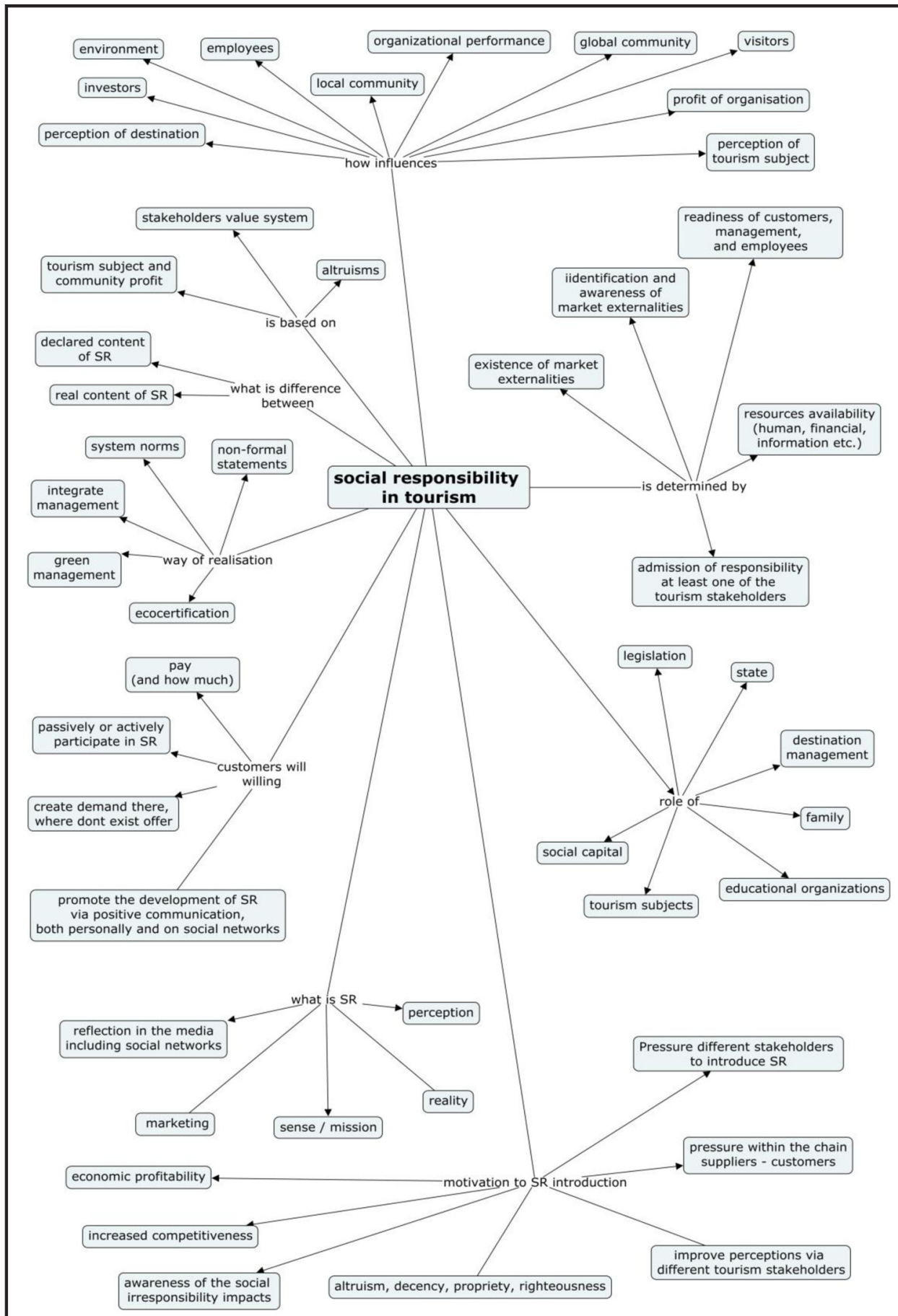

Source: Pásková and Zelenka (2016, p. 782), based on ideas of Kang et al. (2010), Chen et al. (2012), Garay and Font (2012), Parsa et al. (2015) 
the mechanisms enabling the externalities internalizing by the state, regional and local government.

The DPSIR model is very illustrative instrument for description of the causality of social responsibility implementation in the tourism sector, but there are also different tools for that, e.g. "tree of problem" analysis. The implementation of the DPSIR model is demanding on the abstract thinking, some researches may have problem distinguishing various "steps" of its analytical algorithm, mainly between the "state" and "impact".

Mental mapping can serve, e.g. to socially responsible destination management when conducting the key actors' analysis as well as for preparing the ground for strategic planning of sustainable tourism development. Applied to tourism sustainability research, e.g. for tracking socially responsible behaviour of the diverse tourism key actors', this tool is demanding on the holistic modality of thinking.

The concept and implementation processes of tourism social responsibility offer both existing and emerging models, techniques and instruments of how to make tourism more sustainable. It represents a challenge mainly for the destination management organisations as well as for the various tourism associations.

In tourism practice, to achieve a more economically long-term efficient, environmentally safe and socially fair tourism, it seems as helpful to apply the social responsibility concept to the tourism market. This social responsibility concept should be integrated into the general education system (mainly in the frame of programmes focussed on economics, marketing and management) and especially into tourism training and education. In addition, the social responsibility concept should be incorporated into tourism management techniques and apparatus to facilitate its integration into the common activities of the tourism market. The internalization of market externalities offers some solution, however not without the risk of commercialization of the non-commercial items as an immaterial heritage, health, both community and family relationships or environment quality.

Regarding the existing tourism related research, the current approaches to tourism social responsibility comprise diverse topics, of which investigation request involvement of many different disciplines, mainly in the field of the human science. Future research in this field must comprise concepts applicable to social responsibility covering all the three sustainability pillars. The economic pillar should focus on the concepts of destination life cycle, sharing economy and tourism market externalities including the mechanisms of their internalization. The environmental pillar should comprise mainly concepts of destination carrying capacity/limits of acceptable changes, ecosystem services assessment/nature's contributions to people assessment and sustainability impact assessment. The sociocultural pillar should include approaches concerning tourism-related social exchange, tourismrelated acculturation, relational tourism focussed on family interaction and transaction as well as tourism psychographics. Especially, the case studies of concrete tourism facilities, tourism products or tourism destinations could help to deepen the understanding of future potential and present effects of tourism social responsibility for tourism sustainability. Both quantitative and qualitative research of the barriers, opportunities, affecting factors, conditions and effects of the social responsibility implemented by various tourism actors seems to be necessary to understand its real and potential contribution for tourism sustainability. The national tourism organizations, travel agencies, airlines, cruises and bus transport companies, as well as accommodation facilities, interpretative centres, attractions' managers, tourist guides, local inhabitants and other relevant stakeholders have to be among these researched actors. Except of the benefits for tourism sustainability practice, such a research could also assist the process of consolidating the theoretical base of the tourism social responsibility concept, tourism sustainability concept and field of the tourism studies in general. 


\section{References}

Akmese, H., Cetin, H. and Akmese, K. (2016), "Corporate social responsibility reporting: a comparative analysis of tourism and finance sectors of G8 countries", Procedia Economics and Finance, Vol. 39, pp. 737-745, doi: doi.org/10.1016/S2212-5671(16)30273-8.

Aminudin, N. (2013), "Corporate social responsibility and employee retention of 'green' hotels", Procedia - Social and Behavioral Sciences, Vol. 105, pp. 763-771, doi: dx.doi.org/10.1016/j. sbspro.2013.11.079.

Argandonõa, A. (2010), "Corporate social responsibility in the tourism industry: some lessons learned from the Spanish experience", IESE Business School, Working Paper No. 844, available at: http://core.ac. uk/download/files/153/6320426.pdf

Asatryan, R. (2012), "Modelling the cost-benefits of corporate social responsibility (CSR) for decisionmaking in the aviation industry", Advances in Economics, Risk Management, Political and Law Science, Business and Economics Series. WSEAS, pp. 108-113, available at: www.wseas.us/e-library/ conferences/2012/Zlin/EPRI/EPRI-16.pdf

Batle, J., Orfila-Sintes, F. and Moon, C.J. (2018), "Environmental management best practices: towards social innovation", International Journal of Hospitality Management, Vol. 69, pp. 14-20, doi: doi.org/ 10.1016/j.ijhm.2017.10.013.

Bauman, C.W. and Skitka, L.J. (2012), "Corporate social responsibility as a source of employee satisfaction", Research in Organizational Behavior, Vol. 32, pp. 63-86, doi: dx.doi.org/10.1016/j. riob.2012.11.002.

Beder, S. (2011), "Environmental economics and ecological economics: the contribution of interdisciplinarity to understanding, influence and effectiveness", Environmental Conservation, Vol. 38 No. 2, pp. 140-150, doi: 10.1017/S037689291100021X.

Begon, M., Townsend, C.R. and Harper, J.L. (2005), Ecology: From Individuals to Ecosystems, 4th Ed., Wiley-Blackwell, ISBN 978-1-4051-1117-1, p. 750.

Benavides-Velasco, C.A., Quintana-García, C. and Marchante-Lara, M. (2014), "Total quality management, corporate social responsibility and performance in the hotel industry", International Journal of Hospitality Management, Vol. 41, pp. 77-87, doi: dx.doi.org/10.1016/j.ijhm.2014.05.003.

Benitez-Capistros, F., Hugé, J. and Koedam, N. (2014), "Environmental impacts on the Galapagos Islands: identification of interactions, perceptions and steps ahead", Ecological Indicators, Vol. 38, pp. 113-123.

Blackman, A., Naranjo, M.A., Robalino, J., Alpízar, F. and Rivera, J. (2014), "Does tourism ecocertification pay? Costa Rica's blue flag program", World Development, Vol. 58, pp. 41-52, doi: doi.org/ 10.1016/j.worlddev.2013.12.002.

Bonilla-Priego, J., Font, X. and Pacheco-Olivares, R. (2014), "Corporate sustainability reporting index and baseline data for the cruise industry", Tourism Management, Vol. 44, pp. 149-160, doi: dx.doi.org/ 10.1016/j.tourman.2014.03.004.

Buckley, R. (2002), "Tourism ecolabels", Annals of Tourism Research, Vol. 29 No. 1, pp. 183-208, doi: dx. doi.org/10.1016/S0160-7383(01)00035-4.

Budeanu, A. (2007), "Sustainable tourist behaviour - a discussion of opportunities for change", International Journal of Consumer Studies, Vol. 31 No. 5, pp. 499-508, doi: 10.1111/j.1470-6431.2007.00606.x.

Butler, R.W. (1980), "The concept of a tourism area cycle of evolution: implication for management of resources", Canadian Geographer, Vol. 24 No. 1, pp. 5-12.

Cadarso, M.A., Gómez, N., López, L.A. and Tobarra, M.Á. (2016), "Calculating tourism's carbon footprint: measuring the impact of investments", Journal of Cleaner Production, Vol. 111, pp. 529-537, doi: dx. doi. org/10.1016/j.jclepro.2014.09.019.

Campbell, C.L., Heinrich, D. and Schoenmüller, V. (2015), "Consumers' reaction to fair trade motivated price increases", Journal of Retailing and Consumer Services, Vol. 24, pp. 79-84, doi: dx.doi.org/ 10.1016/j.jretconser.2015.02.005.

Caruana, R., Glozer, S., Crane, A. and McCabe, S. (2014), "Tourists' accounts of responsible tourism", Annals of Tourism Research, Vol. 46, pp. 115-129, doi: dx.doi.org/10.1016/j.annals.2014.03.006.

Castellani, V. and Sala, S. (2012), "Carrying capacity of tourism system: assessment of environmental and management constraints towards sustainability", in Kasimoglu, M. (Ed.), Business, Management and 
Economics: "Visions for Global Tourism Industry - Creating and Sustaining Competitive Strategies", ISBN 978-953-51-0520-6.

Chen, F.-Y. (2013), "The intention and determining factors for airline passengers' participation in carbon offset schemes", Journal of Air Transport Management, Vol. 29, pp. 17-22, doi: dx.doi.org/10.1016/j. jairtraman.2013.01.001.

Chen, F.-Y., Chang, Y.-H. and Lin, Y.-H. (2012), "Customer perceptions of airline social responsibility and its effect on loyalty", Journal of Air Transport Management, Vol. 20, pp. 49-51, doi: dx.doi.org/10.1016/j. jairtraman.2011.11.007.

Chen, R.J.C. (2015), "From sustainability to customer loyalty: a case of full service hotels' guests", Journal of Retailing and Consumer Services, Vol. 22, pp. 261-265, doi: dx.doi.org/10.1016/j.jretconser.2014.08.007.

Cherapanukorn, V. and Focken, K. (2014), "Corporate social responsibility (CSR) and sustainability in Asian luxury hotels: policies, practices and standards", Asian Social Science, Vol. 10 No. 8, doi: dx.doi. org/10.5539/ass.v10n8p198.

Choi, H.C. and Sirakaya, E. (2006), "Sustainability indicators for managing community tourism", Tourism Management, Vol. 27 No. 6, pp. 1274-1289, doi: dx.doi.org/10.1016/j.tourman.2005.05.018.

Coccossis, H., Mexa, A. and Collovini, A. (2001), "Defining, measuring and evaluating carrying capacity in European tourism destinations", p. 99, available at: http://ec.europa.eu/environment/iczm/pdf/ tcca_material.pdf (accessed 29 June 2018).

Coles, T., Fenclova, E. and Dinan, C. (2013), "Tourism and corporate social responsibility: a critical review and research agenda", Tourism Management Perspectives, Vol. 6, pp. 122-141, doi: dx.doi.org/ 10.1016/j.tmp.2013.02.001.

De Grosbois, D. (2012), "Corporate social responsibility reporting by the global hotel industry: commitment, initiatives and performance", International Journal of Hospitality Management, Vol. 31 No. 3, pp. 896-905, doi: dx.doi.org/10.1016/j.ijhm.2011.10.008.

Dowling, R.K. (2013), "Global Geotourism - an emerging form of sustainable tourism", Czech Journal of Tourism, Vol. 2 No. 2, pp. 59-79, doi: 10.2478/cjot-2013-0004.

Dowling, R.K. and Newsome, D. (Eds) (2006), Geotourism, Butterworth-Heinemann, Oxford, ISBN 9780750662154, p. 260.

Đurović, M., Jaković, B. and Tubić, D. (2015), "Hotel corporate social responsibility (CSR) reporting", The Macrotheme Review, Vol. 4 No. 6, pp. 50-61.

El Sawah, S. and Guillaume, H., A. (2011), "Using participatory rapid appraisal and DPSIR approaches for participatory modelling: a case study for groundwater management in South Australia", International Congress on Modelling and Simulation, Australia, The Modelling and Simulation Society of Australia and New Zealand. pp. 2873-2879, ISBN 9780987214317.

EPA (2016), "Systems thinking tutorials: DPSIR overview", US Environmental Protection Agency, available at: https://archive.epa.gov/ged/tutorial/web/html/slide0001-2.html (accessed 11 October 2016).

Farooq, M., Farooq, O. and Jasimuddin, S.M. (2014), "Employees response to corporate social responsibility: exploring the role of employees' collectivist orientation", European Management Journal, Vol. 32 No. 6, pp. 916-927, doi: dx.doi.org/10.1016/j.emj.2014.03.002.

Farsani, N.T., Coelho, C. and Costa, C. (2012), Geoparks and Geotourism: New Approaches to Sustainability for the 21st Century, Brown Walker Press, FL, p. 189, ISBN 978-1-61233-551-3.

Fernández, J.I.P. and Rivero, M.S. (2009), "Measuring tourism sustainability: proposal for a composite index", Tourism Economics, Vol. 15 No. 2, pp. 277-296.

Fons, M.V.S., Fierro, J.A.M. and Gómez y Patiño, M. (2011), "Rural tourism: a sustainable alternative", Applied Energy, Vol. 88 No. 2, pp. 551-557.

Font, X., Garay, L. and Jones, S. (2016), "Sustainability motivations and practices in small tourism enterprises in European protected areas", Journal of Cleaner Production, Vol. 137, pp. 1439-1448, doi: dx.doi.org/10.1016/j.jclepro.2014.01.071.

Font, X., Walmsley, A., Cogotti, S., McCombes, L. and Häusler, N. (2012), "Corporate social responsibility: the disclosure-performance gap", Tourism Management, Vol. 33 No. 6, pp. 1544-1553, doi: dx.doi.org/10.1016/j.tourman.2012.02.012. 
Frey, N. and George, R. (2010), "Responsible tourism management: the missing link between business owners' attitudes and behaviour in the Cape Town tourism industry", Tourism Management, Vol. 31 No. 5 , pp. 621-628, doi: dx.doi.org/10.1016/j.tourman.2009.06.017.

Gao, Y.L. and Mattila, A.S. (2014), "Improving consumer satisfaction in green hotels: the roles of perceived warmth, perceived competence, and CSR motive", International Journal of Hospitality Management, Vol. 42, pp. 20-31, doi: dx.doi.org/10.1016/j.jhm.2014.06.003.

Garay, L. and Font, X. (2012), "Doing good to do well? Corporate social responsibility reasons, practices and impacts in small and medium accommodation enterprises", International Journal of Hospitality Management, Vol. 31 No. 2, pp. 329-337, doi: dx.doi.org/10.1016/j.ijhm.2011.04.013.

Gari, S.R., Newton, A. and Icely, J.D. (2015), "A review of the application and evolution of the DPSIR framework with an emphasis on coastal social-ecological systems", Ocean and Coastal Management, Vol. 103, pp. 63-77, ISSN 0964-5691, doi: dx.doi.org/10.1016/j.ocecoaman.2014.11.013.

Garrod, B. and Fyall, A. (1998), "Beyond the rhetoric of sustainable tourism?", Tourism Management, Vol. 19 No. 3, pp. 199-212, ISSN 0261-5177, available at: http://dx.doi.org/10.1016/S0261-5177(98)00013-2

GGN (2016a), "Global geoparks network. global geoparks network best practices award rules and regulations", available at: http://globalgeoparksnetwork.org/wp-content/uploads/2016/05/GGN_BP_Award_ final.pdf (accessed 29 October 2016).

GGN (2016b), "Global geoparks network. Code of ethics", available at: http://globalgeoparksnetwork. org/wp-content/uploads/2016/07/GLOBAL-GEOPARKS-NETWORK-CODE-OF-ETHICS-final.pdf (accessed 29 October 2016).

González-Rodríguez, M.R., Díaz-Fernández, M.C. and Simonetti, B. (2015), "The social, economic and environmental dimensions of corporate social responsibility: the role played by consumers and potential entrepreneurs", International Business Review, Vol. 24 No. 5, pp. 836-848, doi: dx.doi.org/10.1016/j. ibusrev.2015.03.002.

Gössling, S. and Buckley, R. (2016), "Carbon labels in tourism: persuasive communication?", Journal of Cleaner Production, Vol. 111, pp. 358-369, doi: dx.doi.org/10.1016/j.jclepro.2014.08.067.

Hagmann, C., Semeijn, J. and Vellenga, D.B. (2015), "Exploring the green image of airlines: passenger perceptions and airline choice", Journal of Air Transport Management, Vol. 43, pp. 37-45, doi: dx.doi.org/ 10.1016/j.jairtraman.2015.01.003.

Hak, T., Moldan, B. and Dahl, A. (2012), Sustainability Indicators: A Scientific Assessment: Scientific Committee on Problems of the Environment (SCOPE), Island Press, ISBN 9781597266284, p. 448.

Han, H. (2015), "Travelers' pro-environmental behavior in a green lodging context: converging valuebelief-norm theory and the theory of planned behavior", Tourism Management, Vol. 47, pp. 164-177, doi: dx.doi.org/10.1016/j.tourman.2014.09.014

Han, H. and Yoon, H.J. (2015), "Hotel customers' environmentally responsible behavioral intention: impact of key constructs on decision in green consumerism", International Journal of Hospitality Management, Vol. 45, pp. 22-33, doi: dx.doi.org/10.1016/j.ijhm.2014.11.004.

Huang, H.-C.H., Lin, T.-H., Lai, M.-Ch. and Lin, T.-L. (2014), "Environmental consciousness and green customer behavior: an examination of motivation crowding effect", International Journal of Hospitality Management, Vol. 40, pp. 139-149, doi: dx.doi.org/10.1016/j.jhm.2014.04.006.

Hunter, C. and Shaw, J. (2007), "The ecological footprint as a key indicator of sustainable tourism", Tourism Management, Vol. 28 No. 1, pp. 46-57, doi: dx.doi.org/10.1016/j.tourman.2005.07.016.

Illge, L. and Schwarze, R. (2006), "A matter of opinion: how ecological and neoclassical environmental economists think about sustainability and economics", DIW Discussion Papers, No. 619, available at: https://ideas.repec.org/p/diw/diwwpp/dp619.html (accessed 24 October 2016).

Illge, L. and Schwarze, R. (2009), "A matter of opinion - how ecological and neoclassical environmental economists think about sustainability and economics", Ecological Economics, Vol. 68 No. 3, pp. 594-604, doi: dx.doi.org/10.1016/j.ecolecon.2008.08.010.

Inoue, Y. and Lee, S. (2011), "Effects of different dimensions of corporate social responsibility on corporate financial performance in tourism-related industries", Tourism Management, Vol. 32 No. 4, pp. 790-804, doi: dx.doi.org/10.1016/j.tourman.2010.06.019.

ISO (2016), "Discovering ISO 26000", p. 11, available at: www.iso.org/iso/discovering_iso_26000.pdf (accessed 14 May 2016). 
Jha, A. and Cox, J. (2015), "Corporate social responsibility and social Capital", Journal of Banking \& Finance, Vol. 60, pp. 252-270, doi: dx.doi.org/10.1016/j.jbankfin.2015.08.003.

Jurado, E.N., Tejada, M.T., García, F.M., González, J.C., Macías, R.C., Peña, J.D., Gutiérrez, F.F., Fernández, G.G., Gallego, M.L., García, G.M., Gutiérrez, O.M., Concha, F.N., de la Rúa, F.R., Sinoga, J.R. and Becerra, F.S. (2012), "Carrying capacity assessment for tourist destinations. methodology for the creation of synthetic indicators applied in a coastal area", Tourism Management, Vol. 33 No. 6, pp. 1337-1346.

Juvan, E. and Dolnicar, S. (2014), "The attitude-behaviour gap in sustainable tourism", Annals of Tourism Research, Vol. 48, pp. 76-95, doi: dx.doi.org/10.1016/j.annals.2014.05.012.

Kalafatis, S.P., Pollard, M., East, R. and Tsogas, M.H. (1999), "Green marketing and Ajzen's theory of planned behaviour: a cross-market examination", Journal of Consumer Marketing, Vol. 16 No. 5, pp. 441-460.

Kang, J.S., Chiang, Ch.-F., Huangthanapan, K. and Downing, S. (2015), "Corporate social responsibility and sustainability balanced scorecard: the case study of family-owned hotels", International Journal of Hospitality Management, Vol. 48, pp. 124-134, doi: dx.doi.org/10.1016/j.ijhm.2015.05.001.

Kang, K.H., Lee, S. and Huh, C.H. (2010), "Impacts of positive and negative corporate social responsibility activities on company performance in the hospitality industry", International Journal of Hospitality Management, Vol. 29 No. 1, pp. 72-82, doi: dx.doi.org/10.1016/j.ijhm.2009.05.006.

Kang, K.H., Stein, L., Heo, C.Y. and Lee, S. (2012), "Consumers' willingness to pay for green initiatives of the hotel industry", International Journal of Hospitality Management, Vol. 31 No. 2, pp. 564-572, doi: dx. doi.org/10.1016/j.ijhm.2011.08.001.

Kim, Y. and Han, H. (2010), "Intention to pay conventional-hotel prices at a green hotel - a modification of the theory of planned behavior", Journal of Sustainable Tourism, Vol. 18 No. 8, pp. 997-1014. doi: 10.1080/09669582.2010.490300.

Koundouri, P., Ker Rault, P., Pergamalis, V., Skianis, V. and Souliotis, I. (2016), "Development of an integrated methodology for the sustainable environmental and socio-economic management of river ecosystems", Science of the Total Environment, Vol. 540, pp. 90-100, doi: doi.org/10.1016/j. scitotenv.2015.07.082.

Kristensen, P. (2004), "The DPSIR framework. workshop on a comprehensive/detailed assessment of the vulnerability of water resources to environmental change in Africa using river basin approach", UNEP, pp. 1-3, available at: http://wwz.ifremer.fr/dce_eng/content/download/69291/ 913220/file/DPSIR.pdf (accessed 11 May 2016).

Kucukusta, D., Mak, A. and Chan, X. (2013), "Corporate social responsibility practices in four and fivestar hotels: perspectives from Hong Kong visitors", International Journal of Hospitality Management, Vol. 34, pp. 19-30, doi: dx.doi.org/10.1016/j.jhm.2013.01.010.

Lamorski, T. and Dabrowski, P. (2007), "Tourism and its impacts on biodiversity. the case study of Babia Góra national park/biosphere reserve, Poland. case study on guidelines for the preparation of case studies", International Workshop, "Tourism In Mountain Areas", available at: www.cbd.int/doc/casestudies/tour/cs-tour-babia-gora-pl.pdf (accessed 20 October 2014).

Lee, S. and Heo, C.Y. (2009), "Corporate social responsibility and customer satisfaction among US publicly traded hotels and restaurants", International Journal of Hospitality Management, Vol. 28 No. 4, pp. 635-637, doi: dx.doi.org/10.1016/j.jijhm.2009.02.007.

Levy, S.E. and Park, S.-Y. (2011), "An analysis of CSR activities in the lodging industry", Journal of Hospitality and Tourism Management, Vol. 18 No. 1, pp. 147-154, doi: dx.doi.org/10.1375/ jhtm.18.1.147.

López-Mosquera, N. and Sánchez, M. (2012), "Theory of planned behavior and the value-belief-norm theory explaining willingness to pay for a suburban park", Journal of Environmental Management, Vol. 113, pp. 251-262, doi: dx.doi.org/10.1016/j.jenvman.2012.08.029.

Lu, J.-L. and Shon, Z.Y. (2012), "Exploring airline passengers' willingness to pay for carbon offsets", Transportation Research Part D: Transport and Environment, Vol. 17 No. 2, pp. 124-128, doi: dx.doi.org/ 10.1016/j.trd.2011.10.002.

Lynes, J.K. and Andrachuk, M. (2008), "Motivations for corporate social and environmental responsibility: a case study of Scandinavian Airlines", Journal of International Management, Vol. 14 No. 4, pp. 377-390, doi: dx.doi.org/10.1016/j.intman.2007.09.004. 
Mancha, R.M. and Yoder, C.Y. (2015), "Cultural antecedents of green behavioral intent: an environmental theory of planned behavior", Journal of Environmental Psychology, Vol. 43, pp. 145-154, doi: dx.doi.org/ 10.1016/j.jenvp.2015.06.005.

Martínez, P. and Del Bosque, I.R. (2013), "CSR and customer loyalty: the roles of trust, customer identification with the company and satisfaction", International Journal of Hospitality Management, Vol. 35, pp. 89-99, doi: dx.doi.org/10.1016/j.ijhm.2013.05.009.

Matev, D. and Assenova, M. (2012), "Application of corporate social responsibility approach in Bulgaria to support sustainable tourism development", Clean Technologies and Environmental Policy, Vol. 14 No. 6, pp. 1065-1073, doi: 10.1007/s10098-012-0519-9.

Mathew, P.V. and Sreejesh, S. (2017), "Impact of responsible tourism on destination sustainability and quality of life of community in tourism destinations", Journal of Hospitality and Tourism Management, Vol. 31, pp. 83-89, doi: doi.org/10.1016/j.jhtm.2016.10.001.

Mayer, R., Ryley, T. and Gillingwater, D. (2012), "Passenger perceptions of the green image associated with airlines", Journal of Transport Geography, Vol. 22, pp. 179-186, doi: dx.doi.org/10.1016/j. jtrangeo.2012.01.007.

Munday, M., Turner, K. and Jones, C. (2013), "Accounting for the carbon associated with regional tourism consumption”, Tourism Management, Vol. 36, pp. 35-44, doi: dx.doi.org/10.1016/j.tourman.2012.11.005.

Ojeda-Martínez, C., Casalduero, F.G., Bayle-Sempere, J.T., Cebrián, C.B., Valle, C., Sanchez-Lizaso, J. L., Forcada, A., Sanchez-Jerez, P., Martín-Sosa, P., Falcón, J.M., Salas, F., Graziano, M., Chemello, R., Stobart, B., Cartagena, P., Pérez-Ruzafa, A., Vandeperre, F., Rochel, E., Planes, S. and Brito, A. (2009), "A conceptual framework for the integral management of marine protected areas", Ocean \& Coastal Management, Vol. 52 No. 2, pp. 89-101.

Omann, I., Stocker, A. and Jäger, J. (2009), "Climate change as a threat to biodiversity: an application of the DPSIR approach", Ecological Economics, Vol. 69 No. 1, pp. 24-31.

Palmer, T. and Riera, A. (2003), "Tourism and environmental taxes. with special reference to the "Balearic Ecotax'”, Tourism Management, Vol. 24 No. 6, pp. 665-674, doi: dx.doi.org/10.1016/S0261-5177(03)00046-3.

Parsa, H.G., Lord, K.R., Putrevu, S. and Kreeger, J. (2015), "Corporate social and environmental responsibility in services: will consumers pay for it?", Journal of Retailing and Consumer Services, Vol. 22, pp. 250-260, doi: dx.doi.org/10.1016/j.jretconser.2014.08.006.

Pásková, M. (2012), "Environmentalistika cestovního ruchu (Tourism environmentalistics)", Czech Journal of Tourism, Vol. 1 No. 2, pp. 77-113.

Pásková, M. (2014b), "Udržitelnost cestovního ruchu (Tourism sustainability)", Hradec Králové, Gaudeamus, ISBN 978-80-7435-329-1.

Pásková, M. (2014a), "Geoturismus v geoparcích v ČR a ve světě (Geotourism in geoparks in the Czech Republic and in the world)", in Zelenka, J. (Ed.), Modul Prüvodce Ekoturismu a Geoturismu (Ecotourism and Geotourism Guide Module). Gaudeamus Hradec Králové, ISBN 978-80-7435-330-7, p. 158.

Pásková, M. (2015), "The potential of indigenous knowledge for Rio coco Geopark geotourism", Elsevier B.V., Procedia Earth and Planetary Science, Vol. 15, pp. 886-891, doi: 10.1016/j. proeps.2015.08.141.

Pásková, M. and Zelenka, J. (2016), "Social responsibility role in tourism sustainability", in Jedlička, P. (Ed.), Proceedings of International Conference Hradec Economic Days 2016, Vol. 2., Hradec Králové, 2-3 February 2016, pp. 324-331, ISSN 2464-6067.

Phaneuf, D.J. and Requate, T. (2017), A Course in Environmental Economics. Theory, Policy, and Practice, Cambridge University Press, ISBN: 9781107004177.

Pirrone, N.G., Trombino, S., Cinnirella, A., Algieri, A., Bendoricchio, G. and Palmeri, L. (2005), "The driverpressure-state-impact-response (DPSIR) approach for integrated catchment-coastal zone management: preliminary application to the Po catchment-Adriatic sea coastal zone system", Regional Environmental Change, Vol. 5 Nos 2/3, pp. 111-137, doi: 10.1007/s10113-004-0092-9.

Quu, R., Xu, J. and Zeng, Z. (2017), "Carbon emission allowance allocation with a mixed mechanism in air passenger transport", Journal of Environmental Management, Vol. 200, pp. 204-216, doi: doi.org/ 10.1016/j.jenvman.2017.05.036.

Seo, K., Moon, J. and Lee, S. (2015), "Synergy of corporate social responsibility and service quality for airlines: the moderating role of carrier type", Journal of Air Transport Management, Vol. 47, pp. 126-134, doi: dx.doi.org/10.1016/j.jairtraman.2015.05.011. 
Silvis, H.J. and van der Heide, C.M. (2013), "Economic viewpoints on ecosystem services. Wageningen, statutory research tasks unit for nature and the environment (WOT natuur \& milieu)", WOt-rapport 123, P. 68, ISSN 1871-028X, available at: http://edepot.wur.nl/290536 (accessed 26 October 2016).

Sin, H.L. and Minca, C. (2014), "Touring responsibility: the trouble with 'going local' in community-based tourism in Thailand", Geoforum, Vol. 51, pp. 96-106, doi: dx.doi.org/10.1016/j.geoforum.2013.10.004.

Singh, N., Cranage, D. and Lee, S. (2014), "Green strategies for hotels: estimation of recycling benefits", International Journal of Hospitality Management, Vol. 43, pp. 13-22, doi: dx.doi.org/10.1016/j. ijhm.2014.07.006.

Siu, N.Y.-M., Zhang, T.J.-F. and Kwan, H.-Y. (2014), "Effect of corporate social responsibility, customer attribution and prior expectation on post-recovery satisfaction", International Journal of Hospitality Management, Vol. 43, pp. 87-97, doi: dx.doi.org/10.1016/j.ijhm.2014.08.007.

Spanou, E. (2007), "The impact of tourism on the sociocultural structure of Cyprus", Tourismos: An International Multidisciplinary Journal of Tourism, Vol. 2 No. 1, pp. 145-162.

Stanners, D. and Bourdeau, P. (1995), "Europe's environment", The Dobřišs Assessment, European Environment Agency, Copenhagen, p. 676.

Sternberg, R.J. and Sternberg, K. (2016), Cognitive Psychology, 7th Ed., Cengage Learning, ISBN: 9781305644656, p. 596.

Su, X., Wang, H. and Wen, T. (2013), "Profit, responsibility, and the moral economy of tourism", Annals of Tourism Research, Vol. 43, pp. 231-250, doi: dx.doi.org/10.1016/j.annals.2013.07.008.

Torres-Delgado, A. and Palomeque, F.L. (2012), "The growth and spread of the concept of sustainable tourism: the contribution of institutional initiatives to tourism policy", Tourism Management Perspectives, Vol. 4, pp. 1-10, doi: dx. doi.org/10.1016/j.tmp.2012.05.001.

Tosun, C. (1998), "Roots of unsustainable tourism development at the local level: the case of Urgup in Turkey", Tourism Management, Vol. 19 No. 6, pp. 595-610, doi: dx.doi.org/10.1016/S0261-5177(98) 00068-5.

Tsai, H., Tsang, N.K.F. and Cheng, S.K.Y. (2012), "Hotel employees' perceptions on corporate social responsibility: the case of Hong Kong", International Journal of Hospitality Management, Vol. 31 No. 4, pp. 1143-1154, doi: dx.doi.org/10.1016/j.ijhm.2012.02.002.

Tsai, H.-T., Tzeng, S.-Y., Fu, H.-H. and Wu, J.Ch.-T. (2009), "Managing multinational sustainable development in the European Union-based on the DPSIR framework", African Journal of Business Management, Vol. 3 No. 11, pp. 727-735.

UNEP/UNWTO (2005), "Making tourism more sustainable. UNEP a UNWTO", p. 222, ISBN 92-807-25079, available at: www.unep.fr/shared/publications/pdf/DTIx0592xPA-TourismPolicyEN.pdf (accessed 14 August 2014).

UNWTO (2004), Indicators of Sustainable Development for Tourism Destinations. A Guidebook, (English version), ISBN 978-92-844-0726-2.

van den Bergh, J.C. (2001), "Ecological economics: themes, approaches, and differences with environmental economics", Reg. Environ. Change, Vol. 2 No. 1, pp. 13-23, doi: 10.1007/s101130000020.

Weaver, D.B. (2006), Sustainable Tourism: Theory and Practice, Elsevier, Oxford, p. 240, ISBN 978-07506-6438-7.

Witt, C.A. and Muhlemann, A.P. (1994), "The implementation of total quality management in tourism: some guidelines”, Tourism Management, Vol. 15 No. 6, pp. 416-424, doi: doi.org/10.1016/0261-5177(94) 90062-0.

Zelenka, J. and Kacetl, J. (2013), "Visitor management in protected areas", Czech Journal of Tourism, Vol. 2 No. 1, pp. 5-18, doi: 10.2478/cjot-2013-0001

Zelenka, J. and Kacetl, J. (2014), "The concept of carrying capacity in tourism", Amfiteatru Economic, Vol. 16 No. 36, pp. 641-654, ISSN 1582-9146.

Zelenka, J. and Pásková, M. (2012), Výkladový Slovnık Cestovnıho Ruchu (Dictionary of Tourism Terminology), Linde Praha, p. 768, ISBN 978-80-7201-880-2.

Zelenka, J. and Pásková, M. (2016), "Social responsibility in ecotourism", in Jedlička, P. (Ed.) Proceedings of International Conference Hradec Economic Days 2016, Vol. 3, Hradec Králové 2-3. February 2016, pp. 353-359, ISSN 2464-6067. 


\section{Further reading}

Bradley, P. and Yee, S. (2015), "Using the DPSIR framework to develop a conceptual model: technical support document", US Environmental Protection Agency, Washington, DC, EPA/600/R-15/154, available at: https://cfpub.epa.gov/si/si_public_file_download.cfm?p_download_id=527151 (accessed 26 October 2016).

EGN (2000), "The European Geoparks network charter", available at: www.europeangeoparks.org/? page/_id=357 (accessed 14 August 2014).

Sörensson, A. and von Friedrichs, Y. (2013), "An importance-performance analysis of sustainable tourism: a comparison between international and national tourists", Journal of Destination Marketing and Management, Vol. 2 No. 1, pp. 14-21, doi: dx.doi.org/10.1016/j.jdmm.2012.11.002.

UNESCO (2016a), "The English Riviera declaration", p. 1, available at: http://unesdoc.unesco.org/ images/0024/002462/246250e.pdf (accessed 1 November 2016).

UNESCO (2016b), "Application process for aspiring UNESCO global geoparks", available at: www. unesco.org/new/en/natural-sciences/environment/earth-sciences/unesco-global-geoparks/applicationprocess/ (accessed 20 October 2016).

UNESCO (2016c), "Revalidation process of UNESCO global geoparks", available at: www.unesco.org/ new/en/natural-sciences/environment/earth-sciences/unesco-global-geoparks/revalidation-process/ (accessed 20 October 2016).

\section{About the authors}

Martina Paskova is an Assistant Professor at the Recreology and Tourism Department, University of Hradec Králové, focussing her research on indigenous and local tourism, ethno-ecotourism using local-based approach. Since 2002, she works at the Czech Ministry of the Environment as a National Expert for Geoparks Coordination in the position of the Chair of the National Geoparks Network of the Czech Republic. She is also member of the Czech Academy of Science Committee on Environment, Czech Society of Tourism Scientific Experts. Since 2007, she has been assisting the Rio Coco Geopark project (Nicaragua). Since 2011, she serves as an expert for evaluation of the UNESCO Global Geoparks. Martina Paskova is the corresponding author and can be contacted at: martina. paskova@uhk.cz

Josef Zelenka is a Professor at the Recreology and Tourism Department, University of Hradec Králové. His scientific work focuses on the issue of tourism carrying capacity, the landscape perception, the use of ICT in tourism, social responsibility in tourism and environmentalism. He is co-authored by 17 monographs, 27 university study texts, 30 expert articles and several professional studies on ICT in tourism and tourism sustainability. $\mathrm{He}$ is co-founder and member of the editorial board of the Czech Journal of Tourism.

For instructions on how to order reprints of this article, please visit our website: www.emeraldgrouppublishing.com/licensing/reprints.htm

Or contact us for further details: permissions@emeraldinsight.com 